DOI: $10.1515 /$ rpp-2017-0030

Doctor of Humanitarian Sciences, Associate Professor, JAN SIKORA The Maria Grzegorzewska Academy of Special Education Address: 40 Szczęśliwicka St., Warszawa, 02-353, Poland E-mail: jan.sikora@interia.eu

\title{
SOCIAL AND OCCUPATIONAL ACTIVATION OF PEOPLE AT RISK OF SOCIAL EXCLUSION IN POLAND AGAINST THE BACKGROUND OF THE EU COHESION POLICY
}

\begin{abstract}
The subject of the article is social and occupational activation of persons at risk of social exclusion. The phenomenon of social exclusion is an important socio-economic problem today and an important area for the implementation of the priorities of EU cohesion policy. This policy sets out the indicators to be achieved by 2020. Among the specific measures to achieve the set goals particularly significant is the implementation of the concept of supported employment targeted at people at risk of social exclusion. It has been outlined that the core document defining current EU policies and guidelines is the aforementioned "Strategy for Smart, Sustainable and Inclusive Growth, EUROPE 2020" setting out the following key priorities for the focus of for EU Member States: 1) intelligent development development of knowledge- and innovation based economy, 2) sustainable development supporting a more resource efficient, more environmentally-friendly, and more competitive economy, 3) inclusive growth - supporting economy with high employment rate which ensures social and territorial cohesion. It has been stated that "National Strategy for Social Integration for Poland" the areas of exclusion include: 1) living in unfavorable economic conditions, 2) unfavorable effect of social processes resulting from massive, dynamic developmental changes, 3) insufficient life capital, 4) lack of access to appropriate institutions, 5) experiencing discrimination, 6) personal traits that hinder the use of common social resources. It seems that the basis task of a researcher in this context is not so much solving but rather identification of a problem stemming from objective conditions generating phenomena of marginalization and social exclusion. This analytical effort, taken in the frames of different research orientations is aimed at changing mechanisms ruling this process. It is not so much about providing universal solutions as these may be different for each society and must be looked for taking consideration of local economic and specific cultural conditions.
\end{abstract}

Keywords: social cohesion, vocational activation, social exclusion, education.

\section{INTRODUCTION}

Social exclusion is reflected in literature as a subject of social policies. H. Silver (1994), among others, distinguishes three basic concepts exemplified as paradigms of: solidarity, specialization, monopoly (pp. 39-44).

The above are formulated in relation to different manners of propositions of solving social problems, described by political ideologies. The projections included in the concepts are related to indicators having their source in moral directives present in a given culture, social and economic relations or prerogatives stemming from social rights. However, such description has limitation as comes to the explanatory power. 
In this context, it is worth pointing out to deeper analyses conducted on grounds of social systems theories. A short description of functioning of a social system is provided by N. Luhmann (2007) who sees it as constructed vertically in accordance with stratification rule, exemplified in social differentiation stemming from the potential of people forming a society. Functionally, differentiating schemes are selected in an autonomous manner, based on functional problems of a social system. In these circumstances, orientation on a human becomes an ideology, significant only from the point of view of values important for social processes (Luhmann, 2007, p. 182).

In this context placement of an individual in a society becomes a central issue and inclusion of individuals in a social system becomes a process necessary to provide their well-being and proper functioning in a society (Pharo, 2008, p. 99). This assumption may be a good basis and starting point for taking actions to the benefit of people threatened with exclusion and social marginalization.

Although problem of social exclusion and marginalization is universal, while counteracting it, focus must be put on it locally, and it should take consideration of culture, set of values and level of economic activity of a given society.

\section{THE AIM OF THE STUDY}

The aim of the study is to justify occupational activation of people at risk of social exclusion in Poland against the background of the EU cohesion policy.

THEORETICAL FRAMEWORK AND RESEARCH METHODS

Theoretical basis of our study includes the works by E. Babbie (2007), J. Czapiński \& J. Panek (2015), A. Giddens (2004), N. Luhmann (2007), P. Pharo (2008), H. Silver (1994), D. Szacka (2008) and R. Szarfenberg (2006). In addition, we have considered the documents by European Commission, namely, Europe 2020: Strategy for Smart, Sustainable and Inclusive Growth (2010), by the Ministry of Family, Labour and Social Policy, namely, the National Strategy for Social Integration for Poland (Narodowa Strategia Integracji Społecznej dla Polski, 2005), by the Ministry of Development, namely, the National Reform Programme (Krajowy Program Reform, 2016).

While researching, we have used such methods as induction and deduction, analysis and synthesis, generalization, systematization and individualization.

\section{RESULTS}

In the European Union, directional development measures are implemented within the framework of the cohesion policy currently included in the European Commission document entitled "EUROPE 2020. Strategy for Smart, Sustainable and Inclusive Growth". Among the strategic goals for implementing this project are, among others, the objectives of education and social inclusion, considered an important prerequisite for improving the quality of life of citizens.

Within the adopted priorities, the European Commission presented guidelines on: 1) modernizing labor markets and strengthening citizens through the development of professional qualifications through one's whole life in order to increase professional activation rate and better match labor force supply and labor force demand through, inter alia, people's mobility; 2) ensuring social and territorial cohesion so that the benefits of growth and employment are widely available and that the poor and socially excluded can actively participate in society (European Comission, 2010).

One of the significant issues in this context is identification and limitation of these areas of social exclusion which are currently treated as an important socio-economic problem. Significance of this problem stems from the scope and the manner in which this phenomenon occurs. 
In the considerations of social exclusion, attention is usually focused on generators of social inequalities. Depending on the perspective adopted, one can distinguish elements forming the structure of a given type of society or on a hierarchical order of categories of persons categorized by the level of particular characteristics. In empirical research, these inequalities are treated as determinants of life chances of individuals belonging to a particular category and constituting a given society (Szacka, 2008).

In each of these cases, we are dealing with a vision or model of a specific type of society and individuals constituting such society. In the classic sense, the essential criteria for differentiation leading to marginalization and exclusion include economic, social and political factors. However, it must be borne in mind, that the distinction of these conditions does not eliminate their interconnections and dependencies, which substantially complicates the description and diagnosis of the problem.

In this context, we also formulate a mode of understanding exclusion as subject of research. In particular, A. Giddens (2004) defines social exclusion as a result of various types of social disabilities, in result of which an individual or a group cannot fully participate in economic, social and political life of the society to which it belongs.

The core document defining current EU policies and guidelines is the aforementioned "Strategy for Smart, Sustainable and Inclusive Growth, EUROPE 2020" setting out the following key priorities for the focus of for EU Member States: 1) intelligent development development of knowledge- and innovation based economy, 2) sustainable development supporting a more resource efficient, more environmentally-friendly, and more competitive economy, 3) inclusive growth - supporting economy with high employment rate which ensures social and territorial cohesion (European Comission, 2010, p. 5).

Within the aforementioned priorities, social cohesion is an important element understood in the EU documents as a way of functioning in a community where equality of opportunity is ensured for people forming these communities, and manifests itself in the ability to exercise one's basic rights in conditions of prosperity and without any discrimination.

A significant area of actions for such social cohesion is limiting social exclusion, which affects a great number of people in contemporary societies.

Social exclusion occurs in all societies and is expressed in the inability of individuals or groups of persons to participate in important areas of community life to which they belong (Czapiński, Panek, 2015). Social exclusion may touch individuals or groups of people for various reasons, it may be objective or subjective in nature, take many forms, and in analyses it can be treated as a state or process. Treated as a process it includes, in a temporal perspective, the course of changes in socially formed structures that impede some people's access to resources and activities specific to the universally accepted model of society functioning. As a state, it refers to a system of facts forming situations of persons excluded from the normal mode of operation.

In analyses of social exclusion, categories of people at risk of exclusion and areas of social life which may pose a risk of exclusion are usually distinguished. "The National Strategy for Social Integration in Poland", a Polish document on prevention of social exclusion distinguishes the following categories of excluded persons: the disabled, the long-term unemployed or the homeless, as well as exclusion areas, such as: healthcare, education, labor market and social assistance. The expanded catalogue of categories of people at risk of exclusion is included in Art. 7 of the Act of 12 March 2004 on social assistance. Among others, it mentions people and families in need of social care because of poverty, disability, unemployment, helplessness in care and education. 
It is equally important to identify areas of exclusion risk which may touch upon certain individuals or groups; this risk can be analyzed taking consideration of the type and degree/intensity of exclusion. It is important not only to identify the danger area, but also the degree or level of ailments that potentially excluded may experience. In the aforementioned study, "National Strategy for Social Integration for Poland" the areas of exclusion include: 1) living in unfavorable economic conditions, 2) unfavorable effect of social processes resulting from massive, dynamic developmental changes, 3) insufficient life capital, 4) lack of access to appropriate institutions, 5) experiencing discrimination, 6) personal traits that hinder the use of common social resources (Ministerstwo Rodziny, Pracy i Polityki Społesznej, 2004).

The above specified areas or factors of exclusion need clear definition not only of the degree of ailment for an individual, but also determination of the level of participation which may be considered as qualifying individuals or groups to the "excluded" category and determination of its borderline value. In order to ensure practical usefulness of each of the above, an attempt should be made to define their meaning from the perspective of a particular individual and from the perspective of the researcher investigating the problem. In addition, one should bear in mind the interrelations between the abovementioned factors and their importance to the well-being of an individual.

It is worth noting the circumstances characteristic for the exclusion from a point of view of an individual person. Such person is socially excluded if he/she can not, for reasons independent of him/her, participate in activities available to other citizens while he/she wishes to do so (Szarfenberg, 2006, p. 20). Inability must be distinguished from incapacity, in particular the situation of inability without incapacity to participate.

The diversity and interdependence of the factors of social exclusion is the reason why the description of the exclusion mechanism is particularly difficult. Hence, the researching of the phenomenon in question essentially comes down to identifying generators of exclusion and estimating the level of their effects on the basis of indicators specific to each factor or category. Another problematic area is definition of an integrated indicator of social exclusion in a comprehensive way.

In social studies on evaluation of the impact of actions taken to achieve specific results, evaluation research is one of the important ones. Such studies aim at establishment of facts - a result of the implementation of the adopted program for the achievement of the objective pursued. A special case of such research are studies on monitoring social indicators understood as aggregate statistics, reflecting the condition of society or selected social groups (Babbie, 2007).

A separate issue is interpretation of indicators illustrating problems studied. One can distinguish here the indicators characterizing the environment, indicators of undertaken actions and indicators of achieving the set objectives. These indicators can be analyzed simultaneously because of their functional relevance in terms of causes, states - syndromes describing the researched phenomena and reactions including counteracting unfavorable causes and effects from the point of view of implementation of the objectives set.

The application of the indicator-based analysis taking consideration of exposure of the identified causes, state and reactions to the phenomena investigated provides a good basis for a comprehensive analysis of the phenomenon under investigation. However, due to complexity of social exclusion, literature on the subject usually indicates poverty as a state in which an individual can not realize his or her needs. The reasons for this are seen in the exclusion of people from the labor market, due to i.a. low education level and lack of 
professional qualifications, social marginalization resulting from disability or lack of access to social institutions. Hence, the European Commission document on the strategy for smart, sustainable and inclusive growth - Europe 2020 adopted the following key objectives: 1) modernizing labor markets by increasing labor mobility and developing lifelong qualifications, which should in turn be reflected in an increase in the labor force participation rate, 2) fighting poverty in order to ensure social cohesion, which should, in turn, be reflected in dignified life and active participation in society (European Comission, 2010).

The implementation of specific goals should result in: 1) increase in employment rate of people aged $20-64$ from $69 \%$ to at least $75 \%$; 2) reducing the number of early school leavers to $10 \%$ from the current $15 \%$ and increasing the proportion of 30-34 year olds with higher education from $31 \%$ to at least $40 \%$; 3 reducing the number of Europeans living below the national poverty line by $25 \%$ by taking 20 million people out of poverty.

The abovementioned objectives are realized in the European Union through the implementation of the Agenda for New Skills and Jobs and the European platform against poverty and social exclusion. In each EU Member State, the objectives should be achieved on the basis of the National Reform Programs as recommended by the European Council.

In Poland, the document complementary to the Europe 2020 Strategy is the National Reform Program - Europe 2020, updated in 2016. In line with the indicators adopted in the Europe 2020 Strategy, the National Reform Program Europe 2020 adopted the following indicators: 1) employment rate of people aged 20-64 at the level of $71 \%$; 2 ) reducing the proportion of early school dropout to $4.5 \%$ and increasing the proportion of people with higher education aged from 30 to 34 years up to $45 \%$; 3) reduction the number of people at risk of poverty or social exclusion by 1.5 million (Ministerstwo Rozwoju, 2016).

The comparison of these indicators adopted in the EU and in Poland documents is illustrated in Figure 1.

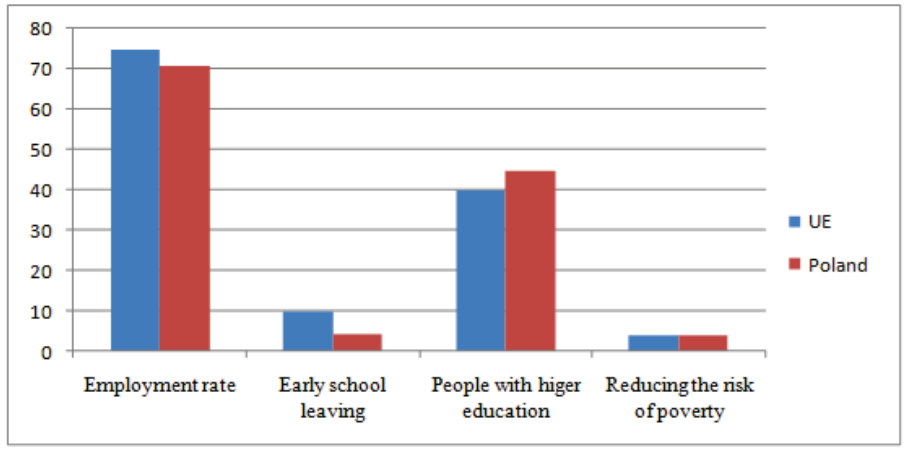

Fig. 1. Indicators for achievement of the 2020 goals of the EU and Poland

Effective action to achieve the goals set in Europe 2020 Strategy for combating poverty and achieving social cohesion is linked to the identification of groups at risk of marginalization and social exclusion. National Strategy for Social Inclusion distinguishes such categories of the excluded as the disabled, the long-term unemployed or the homeless, but also areas of exclusion such as healthcare, education, labor market or social assistance. The expanded catalogue of categories of people at risk of exclusion is included in Art. 7 of 
the Act of 12 March 2004 on social assistance. Among many others, there are people and families who need social care because of poverty, disability, unemployment, helplessness in care and education and others.

Achievement of the strategic objectives mentioned in the aforementioned documents requires effective measures for social inclusion with respect to the fundamentally different categories of persons at risk of exclusion.

Significant groups at risk of social exclusion include: the long-term unemployed, the young between 16 and 18 who have not been in school for at least 6 months, have not worked and have not attended any eductional course, disabled people.

Each of these categories addresses a different set of projects and activities aimed at increasing the level of their social and economic activity, including: European platform against poverty and social exclusion, Youth on the move, European Disability Strategy 2010-2020.

All these programs are encapsulated in detailed activities within the framework of international organizations as well as at the level of EU Member States.

It seems that the common denominator of the situation of each of the aforementioned groups is the general macroeconomic situation expressed in the GDP growth rate, the labour market situation, demographic structure of the society or the tax system.

Another issue is the implementation of specific projects aimed at realization of priorities for social and occupational activation of people at risk of exclusion. A good example of such a project is a concept of supported employment implemented in the European Union. Employment is supported by a project aimed at backing up people at risk of exclusion, especially those with disabilities, in obtaining and maintaining paid employment in the open labor market.

Identification of areas and counteracting social exclusion related to formation of information-based society becomes and open problem. As noted, by M. Castells, the current trend is reflected in absorbing by organizations funded by information technologies, of these individuals who are the most worthy from the perspective of their competence necessary for functioning of the network, and excluding those which are of no value for them (Castells, Himanen, 2009, p. 23). Network becomes the environment to locate processes of power concentration, material goods and information placed in the space of flows, and remaining outside the network forms conditions for marginalization and exclusion for people out of the network. At the same time, one identifies phenomena exemplified in specific homogenization of network users, which may lead to processes of dehumanization of man.

\section{CONCLUSIONS}

It seems that the basis task of a researcher in this context is not so much solving but rather identification of a problem stemming from objective conditions generating phenomena of marginalization and social exclusion. This analytical effort, taken in the frames of different research orientations is aimed at changing mechanisms ruling this process. It is not so much about providing universal solutions as these may be different for each society and must be looked for taking consideration of local economic and specific cultural conditions.

Perspectives for further studies are seen in considering European Commission documents on the development of social policies.

\section{REFERENCES}

1. Babbie, E. (2007). Badania spoleczne w praktyce. Warszawa: PWN.

2. Czapiński, J., \& Panek, T. (2015). Diagnoza spoleczna. Warszawa: RMS. 
3. Giddens, A. (2004). Socjologia. Warszawa: PWN.

4. European Commission, (2010). Europe 2020: Strategy for Smart, Sustainable and Inclusive Growth. Retrieved from http://eur-lex.europa.eu/LexUriServ/LexUriServ.do?uri $=$ COM:2010:2020:FIN:EN:PDF.

5. Luhmann, N. (2007). Systemy społeczne. Kraków: NOMOS.

6. Ministerstwo Rodziny, Pracy i Polityki Społecznej. (2005). Narodowa Strategia Integracji Spolecznej dla Polski. Retrieved from https:/www.mpips.gov.pl/userfiles/ File/mps/NSIS.pdf.

7. Ministerstwo Rozwoju. (2016). Krajowy Program Reform. Retrieved from https://www.mr.gov.pl/media/19320/KPR20162017.pdf.

8. Pharo, P. (2008). Moralność a socjologia. Warszawa: ON.

9. Silver, H. (1994). Social exclusion and social solidarity: three paradigms. Genewa International Institute for Labour Studies.

10. Szacka, B. (2008). Wprowadzenie do socjologii. Warszawa: ON. IPS UW.

11. Szarfenberg, R. (2006). Marginalizacja i wykluczenie społeczne. Warszawa: 